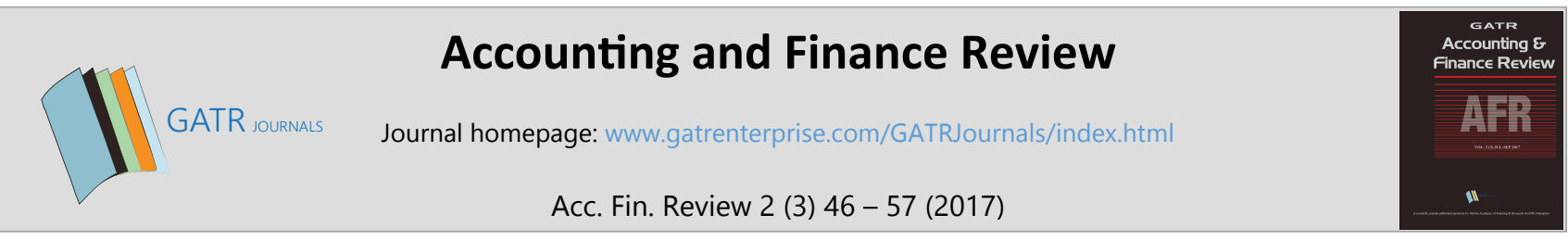

\title{
Dramaturgy Budget Policy Formulation: Intuitive Response of Politics and Power
}

\author{
Syarifuddin $^{1 *}$ and Marwah Yusuf ${ }^{2}$ \\ ${ }^{1}$ University of Hasanuddin, Makassar, Indonesia \\ ${ }^{2}$ STIEM Bongaya Makassar Indonesia
}

\begin{abstract}
Objective - This study aims to capture the perspective people and government in Jembrana Bali about politics and power, as a starting point for budget policy formulation.

Methodology/Technique - The methods used in this study is dramaturgy. It is a method to analyze the front stage and back stage of the actors setting.

Findings - This study found that the way people and government of Jembrana view politics and power is a starting point for budget policy formulation. This study found that accounting man uses power and politics in formulating accounting policies. In this case, actors develop policy as a meaning of the policy for the actors.

Novelty - Unlike another study, this study using dramaturgy to observe human behavior. This technique is more interested in studying people as they are rather than adjusting them into propositions and theories that are already known.

Type of Paper: Empirical.
\end{abstract}

Keywords: Local government; Budgeting; Planning; Dramaturgy; Power; Politics.

JEL Classification: H61, H83, M41.

\section{Introduction}

Accounting as a science has not been widely used, and continue to provide the debates, (such as Burchell et al., 1980; Chua, 1986; Hopper and Powell, 1985; Hopwood and Miller, 1994; Miller, 1994; Irianto, 2004). In accounting disciplines, understanding of budget policy came from the normative approach, in which budget policy limited by decision-making situations which defined in a variety of variables, assumptions, and constraints, as well as objectives. In such regard, a neo-classical view rarely discloses the organizational and human behavior (see Scapens and Arnold, 1986; Scapens, 1991; Ryan et al., 2002). Meaning, there is a little consideration of organizational context, where budget policy operates. Another thing that is overlooked by traditional accounting approach is the potential conflicts that may occur in the organization, as well as the possibility of asymmetric power distribution between goals and behaviours. This mistake appears, according to Morgan (1986), because accounting based on the mechanistic metaphor of an organization.

\footnotetext{
* Paper Info: Received: February 2, 2017

Accepted: July 11, 2017

* Corresponding author:

E-mail: syarifuddin@fe.unhas.ac.id

Affiliation: Faculty of Economics and Business, University of Hasanuddin, Indonesia
} 
Later on, behavioral science with an open social systems approach, known as contingency theory, introduced a less mechanical and more organic view (see Chenhall, 2003). According to Ribeiro and Scapens (2006: 3), the systems get pressured from many variables such as human, structural and environmental, different organizational forms, and mechanisms of coordination, including accounting systems, which is maybe appropriate for various conditions. Therefore, political and power theme became an interesting topic discussed in the context of management accounting. The problem of power and politics is very raw and have been dug deeper from time to time to gain original and perfect policy system formulation which apply to its time.

Power and political terminology have been reviewed and written by scientists in many kinds of literature. Dye (1987: 12) for example, says: "power is the capacity to affect the conduct of an individual is through the real or threatened of rewards and punishment...". This view assumes that politics always involves "shaping and sharing of power" (Laswell et al., 1980: 86). Such that the interesting question for this study is how power and politics reflected in the accounting policies formulation in local government?

Therefore, this study operates policy analysis approach with dramaturgy setting to explain the making of policy, with the intention of putting evidence and interpretation that are relevant to the current period. Thus, the effort used in this study are to not only shed light on topical issues alone, but rather for the fundamental problems that the literature neglected. For this purpose, this study agrees with Chua (1986), where we do not ignore the subjectivity in the collecting or interpretation of data.

The study began with the assumption that the world filled with puzzles and obstacles, and policy as a "black box" or in another term "murky water" that is not transparent. However, through human knowledge [actors] (informant), we can "delve" the shape and background of policy. Meaning, through the mastery of the facts and "knowledge" in policy, it will allow us to describe the birth process of the policy itself (Weber, 1991: 196252).

This study aims to capture the way people and the government of Jembrana view politics and power, as a starting point for budget policy formulation (e.g. free education) in the Jembrana. Therefore, this study tries to observe how accounting man uses power and politics in formulating accounting policies. At the beginning of this study, it discusses the development of policy terms and empirical evidence about the meaning of the policy for the actors.

\section{Theoretical Review}

The discourse on the politics of budget in the context of power and politics, not the discussion of a certainty, but a choice, not a prediction, but rather a construction of the scenario. Moreover, not a linear development, but the development of circular or spiral, and not something that stands alone in his time (partial), but rather a complex network of relations completely with the past and the present (Syarifuddin, 2015).

Keating has argued that 'a good policy process is a primary issue. Of course, the better process does not necessarily guarantee a good policy outcome, but the risks of the bad process leading to a worse outcome are very much higher' (Keating, 1996). At a more basic level, a better policy development process will be rigorous and will broadly follow an organizing framework (Peters and Van Nispen, 1998). Several broad policy frameworks have appeared in the public administration literature over the last 50 years, with refinements along the way (e.g. May and Wildavsky, 1978; Hogwood and Gunn, 1984; Davis et al., 1993; Edwards, 1993; Hawke, 1993; Howlett and Ramesh, 1995; Colebatch, 1998). Much of that literature debates the relevance of what has become known as the 'rational model' of a scientific approach to finding a solution to a problem (Lindblom, 1959). In the literature, the alternative to 'rational' is not 'irrational' but 'incremental,' a process by which decisions are made by building on current policies 'step-by-step and by small degrees' (Lindblom 1959: 81).

Similarly, in looking at the future of the political budget process, is a logical consequence of reform and democratization, which are developed from a holistic perspective. Thus, the built of political reforms will not see as a mere incident, but as a process. In this case, the process considers political change as a system that is 
still ongoing and has not (not even once) finished in a structural budget policy (Overbeck et al., 2006; Ribeiro and Scapens, 2006; Syarifuddin, 2015).

In the context of the process, the phases of construction budget policy go above interpreted. In this case, its describe a process of change that takes place on a large scale at the level of paradigms, structure, social action and the agents. At the level of standards, what happens is the socio-political paradigm shift from authoritarian system towards a democratic regime. At the basic level, a change from centralized structures (center) towards decentralized structures (regions).

At the level of social action, a change from the action is based on the command from above into action (communicative) stemming from the bottom (civil society). Specifically, in the field of political communication, which is underway, is the transition from a closed communications system towards an open communication system. At the text level, a shift from closed text system towards a free text system (Pilliang, 2005: 319). Meanwhile, at the degree of meaning, a change of understanding and a single meaning (monosemy) to plural interpretations and meanings (polysemy). Various levels of this transition show a dynamic ability of the political communication process itself, which changes with the change in the social order.

\section{Methodology}

The study was conducted in Jembrana municipality, Bali between 2015 to 2016 . The study is using the dramaturgical method, while representing a shift towards humanism and avoidance of scientific method. Dramaturgy is more interested in studying people as they are rather than to adjust their behavior abstractions to the propositions and theories that are already known. Human model, as well as the conception of Goffman's sociological theory, is a move that abandons the approaches of grand theories that are already known. Dramaturgy allows individuals to delve into their role. This method evident from the discussion on controlling the impression (which allows mistakes or mismanagement), as well as in the concept of the gap in the roles and links between them.

Therefore, Turner (2005: 12) stated without prejudice to the fact that each human presence is very responsive to the presumption against them, then it is very unfortunate if we assume that this form of selfawareness as to their basic problem in dealing with them. In their association, people do not just sink to the attention remained fixed for the judgment against them and how to influence this way of decisions. This process of association constantly done, and some of them do it more than others. However, this is not the core of what humans do in interacting with them.

Sociologist, Erving Goffman, introduced the dramaturgical perspective in his essay The Presentation of the Self in Everyday Life. In additional, many management scholars have recognized what researchers in social psychology have understood for years. Dramaturgy, or impression management, explains much about behavior in organizational settings. Given the attention and value attached to this concept, it is time for the basic notions that underlie this perspective to be made available to practitioners. Let's start with the key performance elements.

Dramaturgy assumes that in drama there is front stage and back stage where actor and audience interact. Dramaturgy analyses the motives to ingratiate are most common in situations such as the one depicted, where the actor is dependent on a higher status person for the allocation of valuable rewards. Under these circumstances, the Mayor, such as Winasa, often attempts to make themselves more attractive or likable to the target audience. Interestingly, actors often ingratiate themselves with their superiors without being consciously aware of their behavior. Data was collected useful ideas during casual observation; the most powerful insights come from a rigorous analysis of systematically collected data. During research, the researcher will collect photos, video, audio and other contextual data. These pictures or images may look "unpolished" or "rough." However, the beauty of dramaturgy is that what one observes is visually compelling, real and meaningful without being staged. Moreover, by using triangulation, the researcher took the main idea of the actor.

The actor in these studies is all the players in our lives. The extent to which we can lay claim to certain identities depends on our physical attributes such as gender, and attractiveness, our skills and abilities and our 
psychological makeup, including our attitudes, values, beliefs, and personality. Together, these attributes help to determine the kinds of images we desire, and those that we can effectively claim.

The audience, in these studies, is certain essential characteristics of an audience, such as status, power, attractiveness, and familiarity, have a great impact on the ways in which people present themselves. All of us, for example, tend to have a heightened awareness of impressions we create when interacting with high-status audiences such as top executives or celebrities. Where the stage (i.e., situation). Apparently, some situations (e.g., performance reviews, presentations) elicit far different behaviors than others. Some have well-defined norms for expected behaviors (e.g., awards banquets, staff meetings); others, such as an initial meeting of a newly appointed task force, are more ambiguous.

\section{Discussion}

\subsection{Front Stage: Budget Policy Construction}

Today I attended the centennial Boedi Utomo, an organization that stood up and led by young Indonesian. This organization has been the inspiration for raising awareness of the importance of national unity. One hundred years of Boedi Utomo that then became known as the day of national revival interpreted as the increasing momentum of independence. The commander 1617 Jembrana, Lieutenant Colonel. Inf. Wahyudi Amin conveyed the dynamic of the ceremony when he became Inspector at a ceremony commemorating the national revival, Wednesday (21/5) in Pecangakan field, Jembrana. Although it has been a century old, according to Amin, nationality, and unity values that were pioneered by Boedi Utomo is still very relevant to be a guidance for future steps. Aside from being a guidance, a century of national revival should also be a reflection and evaluation of the extent to which these values have applied in our lives as a nation.

"National Revival" momentum is a new spirit of the government of Jembrana to solve the issues of education, where government intervention required for that matter. Gede Winasa, on a separate occasion, stated: "we need to get out of poverty, and the government needs to perform in the future, together with the community." He then added: "to improve the quality of public education in the district of Jembrana, Jembrana district government made a breakthrough in the field of education."

Identifying the problem described previously, subsequently created budget policy formulation. In a historic occasion, Gede Winasa argued: "the slowness in responding to the interest of educational institutions or public complaints, has increased the frequency of criticism, either directly or through the mass media. For example, about the slowness of the provision of educational facilities and educational assistance to students who cannot afford it." Complaints and criticisms from the community to the schools, and schools with the government, in particular on the policies established, deviation implementation of policies, weak controls. The slow process became a wrong signal for democratic development in education for the future. Development of education under the authority of local autonomy requires the participation and support of all parties.

Winasa the Mayor continued, one of the policies that educational institutions are not responsive to the needs of society, but are more toward the interests of the bureaucratic elite, for example, is the policy on service provision and education budget. The Mayor formulates the strategy with clear goals and objectives, which is to the benefit of society, but there are still many poor students, in practice, who do not have the opportunity to obtain an education. Understanding the role of the media and the agenda process as an important factor to consider in the construction of an issue (Ammon, 2010:101), Gede Winasa, then used newspaper media to clarify his ideas. In a local newspaper, he commented: "his policy is an improvement of educational facilities, improving the qualities of teaching and learning for students and teachers. All of the policies will achieve through the imposition of tuition fees entirely on a local budget".

Thus it, appears that Gede Winasa expands the front stage, not only in the office, court ceremony, temple or other formal media, but he also used the newspaper media. For him, the media is useful to define the issues and clarify the issue. The mass media can shape the context in which the policy responses occur and affect the "public opinion" by installing a public agenda on an incident or event. 
According to Ammon (2010:101), the role of mass media in "forming" social issues, is very appropriate. According to him, newspaper media helps a variety of interests and power, build issues/agendas, act as a "spectacle" that dominates the thoughts and actions of the public "audience."

Once again, it is clear that Gede Winasa fully understands the role of media in public policy. In his opinion, the press can bring issues that were previously on the political agenda, into the political arena. Meaning, the media is seen as capable of having a role in a democratic society to make issues "visible." A positive outlook toward the concept of media as an agenda founder can be seen in the study Barbara Nelson about various ways of violence on children and the desire to make issues and public policy (Nelson, 1999).

As Florence Nightingale's famous phrase states, the fact is everything, and the doctrine is nothing (Harris, 1990: 389), then what is done here by public "social" Jembrana is accurate. Where the fact is that they are looking for a major public policy based on empirical data and facts, which is the replacement of thought and action. For them, the truth is often followed by the system and rarely precedes it, as stated by the positivist. Harris (1990: 389) indicated that plans often create a close relationship with actual data that exists.

Here we can see that social fact shapes social policy. The policy is a thesis that shows that facts have a significant influence and accepted by the reformers of social issues. Such systems have established a tradition of government decision-making which focuses on "problem" as well as solutions. In my opinion, the statement where Winasa introduced poverty and all its consequences, allows his voice to be heard by policy makers and persuade them to change direction. In my perspective, Winasa's natural approach to poverty issues in the community come from the initial enthusiasm toward poverty itself. Winasa uses science to solve a problem. As said by Turner (2005:22), the person does not have to be clever, but cunning and accuracy, as well as stable work, is of great value in defining, recognizing and providing a solution to a problem, with attention to the poor conditions. Meaning, cunning, and accuracy itself are a power or source of authority to a particular person.

Drama above illustrates that any facts that are in line with theory expectations may have some social functions, hidden or "latent." Moreover, that society as a whole is seen as the product itself, so for a while, every problem tends to have social causes, and every answer sought itself within the community. In 1940, we can see two lines of development in research on social issues: positivist or functionalist and phenomenological. Positivist or functionalist approach views social problems as "facts" to be measured. The role of social sciences in this approach seeks to identify those conditions (Charteris, 2011). Meanwhile, the phenomenological approach taken from symbolic interactionist class views the problem as a subjective social construction that is important. Here, the role of social science is to clarify the assumptions and definitions, showing the definition of who operates, what alternative viewpoints exist, and identify intervention points. According to Deignan (2010), the second approach has a significant influence in shaping the framework of "circle of life," and a few years later affect some other theories and models.

In the meantime, the drama above also showed that social issues could be analyzed objectively at where they arise, Blumer (1969: 2-6) says that this approach has a central reason, the man interacts with the understanding that they will own everything. Furthermore, understanding is a result of social interaction and understanding is modified and handled through a process of interpretation used by each in dealing with "signs" that he went through. Ricard Fuller is one of the leading critics of the functionalist framework in social issues. He developed the first interaction or constructive analysis. In the late 1930s, he stressed that: we should ignore the notion that social issues represent human behavior, which is the starting point of the cultural status quo that is not questioned and running smoothly (Overbeck et al., 2006: 479-496).

Meanwhile, Overbeck et al. (2006: 479-496) argued that social issues are a deviation condition from the social memorandum that is widely held and have the objective and subjective dimensions. The first observable cause, but the facts may be held to exist, does not that it is deemed to exist. Because of this, the social issue will always be in a dynamic state that eventually becomes a serious matter. On the other hand, Turner (2005:122) suggests that social issues do not follow the footsteps of constant speed or consistency, but in their development, they are more often experience leaps and temporary solution, as well as distance is known as an unoccupied period. 
Therefore, it can be said and set up for those who believe that individuals and communities are a unit that cannot be separated. The public will be understood by the people who built, and in return, people will understand their position as a member of society. Furthermore, since most of the interaction effects experienced in the form of social interaction, the behavior is then formed and interconnected, not disconnected and frees (Overbeck et al., 2006: 479-496). This view is by Paloma (2000: 254) arguments about the big issue of sociology as "imaginations," in a way that the particular social phenomena or social facts are the ones that are right for sociological analysis.

The drama that is on display at the front stage stated above can be analyzed objectively in where the social problem appears. Blumer (1969: 85), who argues that the essence of the society are the actors and their actions. Society is composed of human actions, and people's lives saw as a form of their opinion. Meaning public is an action, a complex group life with ceaseless activity, and there a collective action that requires adjustment and how the action of each becomes a line of from each of the actors who give each their public opinion to each one, not only to their selves.

Public opinion is the political market, what is requested by the customer is a political demand. In a democracy, one can argue that government policies are a function of public opinion. The need specifies the treatments supply. It has become the fact that kind of attention by decision makers with the assumption on the arguments that policy agenda is drawn up by the strength of public opinion and public powers. Because liberal democracy moves the public domain so that public choices can also move, and vice versa. Hogwood and Gunn (1984) stated that to analyze the relationship of public choice on policy, one must know the historical antecedents of the concept. The influence of public views on governance also placed the context of the power to shape public opinion because the idea of public needs is central to democratic theory (Turner, 2005:1-22).

Thus, it said that the determination of policies in the budget sector is a system that is not separate from the surrounding circumstances in which all social, power, politics, economics, history factors and the influence of other factors. Also, the components, the resource allocation process, actors, and power are the factors that play a role in setting policy as a system. As noted by Dafermos et al. (2006), the resulting strategy is a reflection of a series of the vital elite interactions in every detail of the policy making process, including conflicts of interest, the interaction of power, resource allocation.

Policy formation process is not separate from the efforts of certain individuals or groups who seek to influence the decision makers, for policies to be more profitable toward a particular party. All of this is a manifestation of the political power to maintain stability and the interests of each actor. Often, there are, in fact, a control intervention and conflicts of interest between politicians from authorities or agents that have influence in political positions (Attwood, 2007: 233). Therefore, Ribeiro and Scapens (2006: 13) emphasize that: "even in situations of apparent consensus, power is present. Such situations can saw as an important manifestation of the phenomenon of power".

Therefore, it can be said that a series of components, processes, resource allocation as well as actors and power was instrumental in setting budget policy and is considered a system. Therefore, "a reconciliation of various interests and demands which differ from each other to achieve a position of political bargaining is a "murky water," and cannot be viewed transparently by outsiders," explained Nyoman, a lowly clerk in the finance department secretary Jembrana district. Easton (2001) even used the term black box of policy making.

Another word, we can say that the determination of accounting policies is not always the result of the power and politics of one person (even for the most powerful, such as Mayor Gede Winasa). However, it is the product of a series of interactions made by key actors in every detail of policy making process (Easton, 2001: 5-6). In simple terms, the concept of setting policy as a system was proposed by Easton and known as Easton System Model. According to this model, to turn an issue into policy, a system should be able to set the contradictions or conflicts, as well as solutions to the problems. In this case, Easton found issues concerning power distribution and allocation of resources.

Easton models related to how the power system works, ranging from the functioning of input, process, and output. information regarding demands and supports of the community, which will be dealt with by the 
conversion process and turned into outputs (in the form of policy or budgetary decision). Thus, the action of society in input process, the government's actions in the course of converting inputs into outputs, as well as the implementation of accounting policies is a series of political actions in allocating resources of power. Therefore, a system is built on elements that support the system and relies on the interaction between various sub-systems. According to this model, a system will protect itself through three cases; the output is satisfactory, ties rooted itself in the system, as well as the power (Easton, 2001: 5-6).

\subsection{Back Stage: Budget Policy Intuition Reflections Beyond Rationality}

Words can change meaning, that is probably the right term to describe the sense of the policy, which can have different meanings for different people. Although apparently, the term policy, generally agreed upon as something "bigger" than the small decisions, less than a social movement (Parson, 1977).

The modern meaning of policy in English is an action plan and a set of political objectives (see Oxford English Dictionary), while the modern sense of the system used after the second world war is a rational action, as the embodiment of careful consideration. Furthermore, due to the changes in the discourse of a way to legitimize a state, the functions of policy also changed. Hogwood and Gunn (1984: 13-19) detailing the sense of "system" of the modern era in a long row. According to them, the policy is a label for an arena of activity, the expression of a common purpose or desired circumstances, a theory or a model, as well as a rational and logical process.

However, Gede Winasa as a politician has a slightly different understanding with Hogwood and Gun (1984). According to him, "policy is something that other people think is impossible to carry out, if something is rational then everyone can do it. If it had never done by others, but it is rational, then it is also something general." Thus, Winasa concluded that the policy is unique if people doubted that it could implement. The comprehensive plan was born from a "perfect" process, a process that balances the "logic" and "intuition" (italics added for emphasis).

According to Day (2006: 12), intuition is an internal mechanism that helps in making decisions. Intuition is often called a hunch, instinct, or the sensation of something that tells you to go in a particular direction. Intuition gives the tools to make strong decisions. The one that makes basic education fee waiver policy (first in Indonesia) Winasa apparently trying to break the "mass mind" about the intuition that has a dubious reputation. As is known, the conventional thinking rejected intuition as something intangible, mystical, and untrustworthy. Therefore, people who use intuition regarded as the "visionaries." The evidence from Jembrana districts presented indicates that the view of the conventional thinking is the myths and misconceptions. Although intuition has a very smooth connotation, I believe that it can use in ways that are very practical. Intuition can be used to express the right information, can be touched, and reliable, or in other words, useful (italics added for emphasis).

The turns Winasa view is in line with the philosophy concept of Socrates and Plato, who lived during 466$399 \mathrm{BCE}$ and 427-348 BC. In the discussion on mental imagery, they argue that humans are taught to think out of the box and free from the limitations of the practical, tangible, sensible labeled concepts and other things that are in the human mind. Man must go beyond the rational mind, imprisoned in the body as a captive and powerless, with hands and feet in chains, forced to see the reality indirectly, but only through the bars of the prison of the body. The body is the trap of soul, which hinders the search for truth. In a sense, the body is a grave of the soul that caught up in desires and the evil temptation of the body (Audifax, 2006: 240). Therefore, according to Stoicism Philosophy, Seneca (65 BC) said that Stoicism is the dominant philosophy in the Roman Empire at the turn of the millennium zero and give an unyielding influence on Christian thought during their formative years.

A man whose high-minded and senses to split the soul from the body and placing it as part of something better, or make it a part of something divine, and as far as possible he should avoid contact with this delicate parts. Moreover, once again, "nature has surrounded our soul by giving it a body as its cloak" (Synnot, 2002: 16). As the view of Socrates and Plato, Seneca seems to have a more moderate view. He does not resist the 
body, but just think of it as a cloak and not a grave or prison. Indeed cloak protects only the elements in it, but he is not as important as the wearer's coat.

From the above description of the body and soul, we can say that in formulating policies do not get caught in the rational mind of the body, but we can use intuition or instinct and heart that goes beyond the mind. Because intuition is a device that is "stronger" and cannot be lost among the other components in the decisionmaking process, as we can not ignore the emotional and intellectual. Because, as we understand, if we will decide on what kind of policies and why the system took, then we will make clearer rational decisions. Therefore, I am amazed at policy tools that use intuition and irrationality or "emotionality" that correlate with the facts, feelings, and thoughts.

Thus, it is evident how small the consideration of policy making in a secular society or people who are less interested in religious values and their inner-self situation, including intuition. In this context, secular society always demands politicians who make policies must certify that they did something after considering it rationally, by ignoring the emotional aspects, especially spiritual intuition.

However, the policy remains a policy that could have a different meaning for everyone. That is, the system is complex and has a rich sense. "Policy" for Shakespeare, for example, has a variety of meanings. On one occasion, he called "precautionary," while on other times he translates it as a "form of government," "administrative affairs," and as "Machiavellianism." Based on that causes many people to assume that a policy that covers the art of illusion can interpret as a natural result. Thought Machiavelli Niccolo, in his book Il Principe, formulate a policy as something separate from the moral as well as tend to be practical. For Machiavelli, separation of moral is necessary because, in the middle of the chaos in the religious realm and moral disintegration in public, is not prefer the moral legitimacy, but an issue of power. According to him, the goal of policy formulation is to make the unstable power becomes stable and sustainable. Therefore, Machiavelli stressed that the aim of all the efforts of all the rules of politics is to secure the powers at their hand. According to him, the holder of authority is not the personification of the moral virtues (Machiavelli, 2010: 61-63). Thus, Machiavelli put policy formulation and morality as two separate fields and no relation to one another. In matters of policy formulation, there is no place to talk about morals. Because the absence of ethical values and intuition in life led to a power-holders, who could also formulate a policy by the agreements that have been made or even break a promise, an oath of office, the contract of politic or whatever they called, although it never uttered in various occasions. Politics and duplicity, where appearance is something we could see, and illusion is material to exercise power. Shakespeare used the term Machiavellian philosophy that has been widely recognized at the time, which means that power cannot take place only by force. In Shakespeare view, Machiavelli doctrine teaches that power requires policy, and "policy is above consciousness," this understanding is evident in his work Timon of Athens (Parson, 1997).

In another part, Francis Bacon, who lived in the same era as Shakespeare, defining the policy regarding "a cunning rationality." Although after sometimes, Bacon change the explanation of policy as a political and a political as a policy, is replaced by the idea of it as a political time in carrying out, or apply them as "administrative" or "bureaucratic." Thus, I then agreed with the Putu Sukarta phrase a department head that the legitimacy of the ruler comes from the recognition to be non-political, while politicians claim that their authority rests on the approval of their policies or "platforms" with their voters.

In my opinion, this statement indicates that the policy as a term that turns into the disclosure of political rationality. That is, having a policy is to have a reason or rational argument, which contains a statement for an understanding of the problem and its solution. From here, it can trace further that the policy offers a theory similar to the declarations made by legitimacy. For this, Raka Muliarte a powerful regional politician discloses: Politicians should have "policies," as the store expected to supply the goods for sale. In the sense that "realistic" about democracy, " policy" an important aspect of the free exchange.

Therefore, Muliarte added, all politicians will, of course, be ready at any time to equip itself with the backup principles or essential part of the principles, which are as important as brands of goods sold in department stores. That is, the politicians use the policy as a response to the need (or the problem) community. Hence, 
Attwood (2007: 233-237) suggests that psycho-techniques management party such as advertising, slogans, and party songs, is not just accessories, but the essence of politics.

Evidence obtained from Muliarte above shows that the idea of the policy as a "product" has the consequence of developing a neutral connotation, moving away from the Machiavellian thinking exhibited in Shakespeare. Muliarte is making policy and politics in terms that are completely different. He made a language and rhetoric of the policy as an important instrument of political rationality. As is, from Laswell observation (1951b: 5) that the word "policy" is used to design the most important choice, both in the context of the public or in private life. According to him, "policy" has been free from unwanted connotations, such as the slanted meaning of "partisan" or "corruption" attitude.

The slant, meaning was born as a result of the concept of a liberal democratic system, which encourages political elites should [only] give a rational reason for what they are proposing or doing (Parson, 1997: 45). According to Gede Winasa: "in a religious society, perhaps it would be better if a policy or decision based on the teachings of the religion, so it is legitimate."

Thus, it said that in the budget policy the power of language and symbols have a very central role in shaping hegemony, especially as a medium for the formation of public opinion. Hegemony over budget policies is not only in the form of the domination of the idea or belief alone, but the whole process of ideological power represented via signs, meanings, and values behind it. In the budget policy, language, symbols, meanings, and those dominant values are always questioned, challenged, resisted, and through various forms of political struggle signs.

In other words, if the budget policy is a hegemony battleground, namely the battle of ideas, and ideologies through the mechanism of language, signs, and symbols, then he demanded democratic foundations formed between the roller and the group controlled, especially at the level of ideology. That is, the way of life of a community of nations is not the view of life from hegemony class imposed passively (toersire). However, it is the result of the struggle for power in articulating the views of existing life, from a variety of different social groups, are then joined by a principle of articulation that is managed by a hegemony class.

The above pictures show that budget policy observed as a shared space for various interest groups, in which the struggle of hegemony happen all the time, and in it, the notion of ideology is won, challenged/changed in the process of free competition. That is, by the principle of hegemony as a form of articulation of civil society, there should be an effort of the various instruments of power or public institutions such as the media to absorb and articulate the interests and ideologies that exist. This effort is necessary to shape public opinion that is healthy and achieve wider audience acceptance.

When the budget policy understood as a container, in which various social groups can communicate and realize the aspirations and interests, then in a particular time scale in that space will crystallize what is called a culture, in the broadest sense. When in the budget policy meet and intersect with various social groups with different interests, then in budget policy is formed different cultures, in a plural sense.

Although one culture and another (based on ethnicity, race, region, religion, profession, social group) can conflict with each other, the budget policy has a duty to accommodate and make room for all these cultures. When different cultures are present together in the shared space, it will allow the principles, form, value or meaning to build on them, that is shared (common culture) by various cultural groups with interest in a budget policy.

The above pictures had previously been pointed out by Deignan (2011: 57-60). In the case of influencing person's opinion, one thing that seems quite prominent is the value held by any individual or organization. A religious community, for example, has different values with secular society. The difference in value is making a difference in people's motivations and behaviors. It is often also referred to the ideal framework.

Moreover, it appears that the policies mentioned above formulated well in a framework called an interactionist symbolic framework. It states that meaning and the "reality" socially determine through a process of interaction of people with each other, which reached the definition of mutual against the social situation, and collectively could produce an agreement on "what is" (Blumer, 1969: 4). In this case, the budget policy 
creating a shared meaning. Thus, a budget plan is a physical reality, and therefore a strong consensus cannot make it disappear or change. However, the "meaning" of the budget policies may vary and change according to the consensus of people associated with him.

\section{Conclusion and Recommendations}

This study found that the way people and government of Jembrana view politics and power is a starting point for budget policy formulation. This study found that accounting man uses power and politics in formulating accounting policies. In this case, actors develop policy as a meaning of the policy for the players. This study goes into more synthesis models in convergence approaches, from now on called a "macro" problem of the policy process. The early part of this study uses the metaphor of the policy process, including intuitive.

The study found that politics is not something as simple as proposed by Lasswell, which is about "who get what, when and how" but also "who gets left out, when and how." The study found that political power consists of something else, namely an ability to influence the resolution of a local political issue, which includes the capacity to keep a few things before they become a problem and provides a variety of capabilities to deter the level of development issues. Furthermore, the power does not require an exercise to be more efficient because the power has sufficient ability to limit the scope of the decision-making object.

Thus, special power lies in the capacity to perform an action. The existence of such a power raises an opposition on public confidence that decision-making is open and can press or penetrate. The study found that stakeholders agree that the education problem is a social issue. For them, social problems similar to human body pathology issue. In the case of a malfunction, there is a momentum that where or how the body is supposed to work and is wrong to consider that it is an objective disorder. That is, the problem of education is the result of politics and strength.

This study suggests the main idea that is to fully understand the social problems we have to know how the problem define as "a social issue." Formulation of social problems is primarily the result of a political process. A process in which public action would take. Thus, a policy moves through the circle of definition. Some important aspects of this ring in a policy formulation are that they are not an objective reality, but is a product of "collective behavior." The plan made from the process which seen and defined in the community.

\section{References}

Ammon, U. (2010). World languages: Trends and futures. The handbook of language and globalization, 101-122.

Attwood, F. (2007). Sluts and riot girls: Female identity and sexual agency, Journal of Gender Studies, 16(3), 233-47.

Audifax. (2006). Imagining Lara Croft, Jalasutra, Yogyakarta.

Blumer, H. (1969). Symbolic Interactionism: Perspective and Method, New Jersey, Prentice Hall Inc.

Blumer, H. (1971). Social problems as collective behavior, Social Problems, 18(1), 298 - 306.

Burchell, S., Clubb, C., Hopwood, A.G., Hughes, J., \& Nahapiet, J.C. (1980). The Roles of Accounting in Organizations and Society, Accounting, Organizations, and Society, 5(1), 5 - 27.

Charteris-Black, J. (2011). Politicians and rhetoric: The persuasive power of metaphor. Springer.

Chenhall, R.H. (2003). Management control systems design within its organizational context: findings from contingencybased research and directions for the future, Accounting, Organizations, and Society, 28(1), 127-168.

Chua, W. F. (1986). Radical developments in accounting thought. Accounting review, 601-632.

Colebatch, H.K. (1998). Policy, Buckingham: Oxford University Press.

Dafermos, M., Marvakis, A., \& Triliva, S. (2006). Critical psychology in a changing world: Contributions from different geo-political regions Special Issue. Annual Review of Critical Psychology, 5.

Davis, G., Wanna, J., Warhurst, J., \& Weller, P. (1993). Public Policy In Australia, Sydney: Allen \& Unwin.

Day, L. (1997). Practical Intuition: How to Harnes the Power of Your Instinct and Make It Work for You, New York Times, in translated edition Day, L. (2006), Cara Mudah Menajamkan dan Menggunakan Intuisi Dalam Pekerjaan Dan Kehidupan Pribadi, PT Serambi Ilmu Semesta [Easy Sharpenening and Using Intuition In Work And Personal Life, PT Serambi Ilmu Semesta], Jakarta. 
Deignan, A. (2010). The evaluative properties of metaphors, in Low, G., Todd, Z., Deignan, A., \& Cameron, L. (2010), (eds), Researching and Applying Metaphor in the Real World. 357-73, Amsterdam and Philadelphia: Benjamins.

Deignan, A. (2011). Deliberateness is not unique to metaphor: A response to Gibbs, Metaphor and the Social World, 1(1), $57-60$.

Dye, T.R. (1987). Power, and Society, 4th Edition, Monterey, California: Brooks/Cole Publishing Company.

Easton, D. (2001). Political System Analysis, in Mas'oed, M., \& Mac.Andrews, C. (2001), translated edition, Perbandingan Sistem Politik [Comparison of Political Systems], Yogyakarta: Gadjah Mada University Press.

Edwards, M. (1993). Child Support Scheme: Policy Development Processes and Practices, based on a presentation to AIC Conference, April, Mimeo.

Harris, J. (1990). Economic Knowledge and British Social Policy, Accounting Organizations, and Society, 10(3).

Hawke, G.R. (1993). Improving Policy Advice, Institute of Policy Studies, Victoria University of Wellington, Wellington: Printing Press.

Hogwood, B.W., \& Gunn, L. (1984). Policy Analysis in the Real World, Oxford: Oxford University Press.

Hogwood, B.W., \& Gunn, L.A. (1984). Policy Analysis for The Real World, London: Oxford University Press.

Hopper, T., \& Powell, A. (1985). Making Sense of Research in the Organisational and Social Aspects of Management Accounting: A Review of Underlying Assumptions, Journal of Management Studies, 22(3), 429 - 65.

Hopwood, A.G., \& Miller, P. (1994). Accounting as Social and Institutional Practice, Cambridge: Cambridge University Press.

Howlett, M., \& Ramesh, M. (1995). Studying Public Policy, Toronto: Oxford University Press.

Irianto, G. (2004). A Critical Enquiry Into Privatization of State-Owned Enterprises: The Case of PT. Semen Gresik (Persero) Tbk. Indonesia, Unpublished Ph.D. Thesis, The University of Wollongong, Australia.

Keating, M. (1996). Defining the policy advising function. Evaluating Policy Advice: Learning from Commonwealth Experience, 61-68.

Laswell, H.D. (1951b), The Policy Orientation, in Laswell, H.D., Lerner, D., \& Speirer, H. (1980), Propaganda and Communication in World History, University Press of Hawai, Honolulu.

Laswell, H.D., Lerner, D., \& Speirer, H. (1980). Propaganda and Communication in World History, Honolulu: University Press of Hawai.

Lindblom, C.E. (1959). The Science of "Muddling Through", Public Administration Review, 19, 78-98.

Machiavelli, N. (2010). The Prince, Microsoft Press, http://gen.lib.rus.ec/book/index.php? md5.

May, A., \& Wildavsky, A. (1978). The Policy Cycle, Beverly Hills, CA: Sage.

Hopwood, A. G., \& Miller, P. (1994). Accounting as social and institutional practice (Vol. 24). Cambridge University Press.

Morgan, B. (1986). Images of Organization, Sage, California.

Nelson, B. J. (1999). Diversity and public problem solving: Ideas and practice in policy education. Journal of Policy Analysis and Management, 18(1), 134-155.

Overbeck, J. R., Tiedens, L. Z., \& Brion, S. (2006). The powerful want to, the powerless have to: Perceived constraint moderates causal attributions. European Journal of Social Psychology, 36(4), 479-496.

Parsons, W. (1997). Public Policy: An Introduction to the theory and practice of policy analysis, UK: Edward Elgar Publishing Limited.

Peters, B.G., \& Van Nispen, F.K. (1998). Public Policy Instruments: Evaluating the Tools of Public Administration, Cheltenham, UK: Edward Elgar.

Pilliang, Y.A. (2005). Transpolitics: Political Dynamics in the Virtuality Era, in translated, Pilliang, Y.A. (2005), Transpolitika: Dinamika Politik di dalam Era Virtuality [Transpolitics: Political Dynamics in the Virtuality Era], Yogyakarta: Jalasutra.

Poloma, M. (2000). Contemporary Sociology Theory, in translated edition, Poloma, M. Sosiologi Kontemporer, Jakarta: PT. Raja Grafindo Pesada.

Ribeiro, J.A., \& Scapens, R.W. (2006). Management Accounting and Power: A Contested Relationship, http://www.fep.up.pt /investigacao/cete/papers/dp0611.pdf.

Ryan, R.J., Scapens, R.W., \& Theobald, M. (2002). Research Methods and Methodology in Accounting and Finance, 2nd Edition, London: Thomson.

Scapens, R.W. (1991). Management Accounting: a review of recent developments, 2nd Edition, London: MacMillan.

Hopwood, A., Allen, D., Kirwan, M., Johnson, H. T., Robert W. Scapens, Arnold, J., ... \& Goold, M. (1986). Research and current issues in management accounting. Pitman \& Sons. 
Syarifuddin. (2015). The Dramaturgy of Politics and Power in Determining Budget Problem in District Jembrana, Bali, Procedia Social and Behavioral Sciences, 211, 375-382.

Synnot, A. (2002). The Body Soul, New Edition, Routledge Publisher, London.

Turner, J.C. (2005). Explaining the nature of power: A three-process theory, European Journal of Social Psychology, 35 , $1-22$.

Weber, M. (1991). From Max Weber: Essays in Sociology, ed., London: Routledge. 